\title{
DIGITAL RADIOGRAPHIC EVALUATION OF OPTICAL DENSITY OF PORCELAINS USED FOR FABRICATION OF INLAY/ONLAY PROSTHESIS
}

\author{
AVALIAÇÃO DA DENSIDADE ÓPTICA DE PORCELANAS USADAS PARA CONFECÇÃO DE \\ PRÓTESES INLAY/ONLAY POR MEIO DE RADIOGRAFIA DIGITAL
}

\author{
Julio Cezar de Melo CASTILHO ${ }^{1}$, Wilton Mitsunari TAKESHITA², Luis Roque de Araújo dos SANTOS², Luiz Cesar de MORAES ${ }^{3}$, \\ Edmundo MEDICI FILHO ${ }^{3}$, Mari Eli Leonelli de MORAES ${ }^{4}$
}

\author{
1- DDS, MScD, PhD Professor, Discipline of Radiology, Department of Surgery, Periodontology and Radiology, São Paulo State University, \\ São José dos Campos, Dental School, Brazil. \\ 2- DDS, MScD, PhD Student - Department of Surgery, Periodontology and Radiology, São Paulo State University, São José dos Campos, \\ Dental School, Brazil. \\ 3- DDS, MScD, PhD, Chairman - Discipline Radiology, Department of Surgery, Periodontology and Radiology, São Paulo State University. \\ São José dos Campos, Dental School, Brazil. \\ 4- DDS, MScD, PhD, Professor, Discipline of Radiology, Department of Surgery, Periodontology and Radiology, São Paulo State University, \\ São José dos Campos, Dental School, Brazil.
}

Corresponding address: LUIS ROQUE DE ARAUJO DOS SANTOS - Department of Surgery, Periodontology and Radiology - discipline of Radiology - São José dos Campos Dental School, São Paulo State University - AV. Engenheiro Francisco José Longo, 777 - Jardim São Dimas Cep.: 12245-000 - São José dos Campos-SP - luisroquearaujo@hotmail.com

Received: February 21, 2005 - Modification: May 10, 2005 - Accepted: May 31, 2005

\begin{abstract}
$T_{1}$

he purpose of this article was to compare the mean value of optical density of four porcelains commonly used for fabrication of inlay/ onlay prostheses using direct digital radiograph. The sample consisted of 202 -mm thick porcelain specimens (measured by digital pachymeter): Empress (Ivoclair), Simbios (Degussa), Vita Omega 900 and Vitadur Alpha (Vita Zahnfabrik). The values of optical density of the specimens were expressed in millimeters aluminum equivalent (mm eq Al). The samples were $\mathrm{X}$-rayed using two charge coupled devices (CCD) - RVG (Trophy) - Visualix (Gendex) and a phosphor plate system - Digora (Soredex). The optical density reading was performed with Image Tool 1.28 in a total of 110 measurements. Statistical analysis showed that there were statistically significant differences in all materials studied $(\mathrm{p}<0.05)$ regardless of the radiographic system used. The highest optical density value was found for Omega 900 (1.8988 mmeqAl - Visualix - Gendex) and the lowest for Vitadur Alpha (0.8647 - Visualix - Gendex). Thus, the material presenting the highest degree of optical density was Omega 900, Empress and Simbios presented intermediate optical density values, Vitadur Alpha presented the lowest value, and the optical density of porcelains was not influenced by the digital radiography systems.

Uniterms: Digital radiography; Dental porcelain.
\end{abstract}

\begin{abstract}
RESUMO
objetivo desse trabalho é comparar valores médios de densidade óptica de quatro porcelanas comumente utilizadas para confecção de inlay/onlay por meio da densidade óptica usando radiografia digital. A amostra constou de 20 corpos de prova com espessura de $2 \mathrm{~mm}$ (mensurados em paquímetro digital) das porcelanas: Empress (Ivoclair), Simbios (Degussa), Vita Omega 900 e Vitadur Alpha (Vita Zahnfabrik). Os valores de densidade óptica das amostras foram expressos em milímetros equivalente em alumínio (mm eq Al). Os espécimes foram radiografados, utilizando dois sistemas de dispositivo de carga acoplada (CCD) - RVG (Trophy) - Visualix (Gendex) e um sistema de placa de fósforo - Digora (Soredex). A leitura da densidade óptica foi realizada no programa Image Tool 1.28 totalizando 110 medições. As leituras de densidade ópticas foram feitas no programa Image Tool 1.28 totalizando 110 mensurações. A análise estatística demonstrou que houve diferença estatisticamente significante entre a densidade óptica das porcelanas estudadas independentemente do sistema de radiografia empregado ( $<$ 0,05). A porcelana Omega 900 obteve 1,8988mmeqAl - Visualix - Gendex e Vitadur Alpha 0,8647mmeqAl - Visualix Gendex. Conclui-se que a porcelana Omega 900 apresentou os maiores valores de densidade óptica, enquanto que Empress e Simbios obtiveram valores intermiediários, Vitadur Alpha apresentou os menores valores de densidade óptica e a densidade óptica das porcelanas não foram influenciadas pelo sistema de radiografia digital.

Unitermos: Radiografia digital; Porcelana dentária.
\end{abstract}




\section{INTRODUCTION}

Since long ago, man has searched for restoration of esthetics and masticatory function in order to meet these requirements satisfactorily. The materials employed comprised metal alloys, silver amalgam and resins. Buonocore (1955) suggested the utilization of acids to alter the tooth surface and make resins more suitable.

By thinking this way, porcelain was the material that met these requirements. Porcelain has recently been introduced in dentistry, and its use as a restorative material began about 200 years ago, but it was in the 80s that a big push was given, with the appearance of the new generation of porcelains, composites and dental adhesives that contributed for the development of indirect techniques for application in posterior teeth such as inlay/onlay ${ }^{24}$.

These materials should present various characteristics. They should have good biocompatibility, adaptation to the cavity margins, good adhesion to dental tissues, resistance to wear and decay, and easy manipulation. The material must present a radiopacity different from the dental tissues to enhance definition of the presence or absence of recurrent caries and also a proper cervical adaptation and proximal contour of the restoration (Takeshita, et al, ${ }^{22}$; Tamburus ${ }^{23}$ ). To get to this point, the inclusion of radiopaque elements with high atomic number is necessary (barium zirconium, zinc, ytterbium and lanthanum) in organic particles (Bouschlicher, et al.5; Van Dijken, et al. ${ }^{24}$; Willans and Billington $^{25}$ ). According to Curtis, et al. ${ }^{9}$, the manufacturers can control the optical density of materials through selection of the polymeric matrix, however the nature of elements, their different sizes and densities may remarkably influence this condition ${ }^{8,9,22}$.

The digital image became reality in dentistry in 1987 with the Radio VisioGraphy system (Trophy Radiologie, Vincennes, France) (Nelvig, et al. ${ }^{18}$ ). Dynamically, new products came out into the dental market, with basically two concepts concerning image capture: the first consists of a sensor, called CCD (charge coupled device), which has a wire connected to a computer, and the other has a phosphor storage system as a photon-detector, which has the same size and thickness of the periapical film and does not have connected wires, thus depending on an appropriate scanner to yield the image after X-ray exposure ${ }^{4,14,19}$.

According to Khademi ${ }^{14}$ the digital image allowed visualization of radiographic images, considering that with an image treatment program and a computer it is possible to alter them, improving the differentiation of density and contrast of gray tones in case of failure of human visual acuity. The professional should be aware of the different densities existing among the various porcelain types; besides, he or she can distinguish it from other materials, caries and other problems (Fenyo-Pereira ${ }^{10}$; Graziottin, et al. $\left.{ }^{13}\right)$. In view of this, the present paper studied porcelains commonly used for inlay/onlay and verified the degree of optical density by means of digital radiography.

\section{MATERIALAND METHODS}

In this study, 4 commonly used porcelain brands were used for fabrication of inlay/onlay prostheses: Empress (Ivoclar, Liechtenstein, Germany), Simbios (Degussa, Hanau, Germany), Vita Omega 900 and Vitadur Alpha (Vita Zahnfabrik, Säckingen, Germany).

The porcelain samples were made in the prostheses lab at São Paulo State University (UNESP), from an aluminum matrix with an $8 \mathrm{~mm}$ diameter orifice, $2 \mathrm{~mm}$ thick according to specification number 57 of the American Dental Association ${ }^{2}$ which states that the radiopacity of composite resins must be superior to that of an equal thickness in aluminum. According to Van Dijiken, et al. ${ }^{24}$ restorations are up to $2 \mathrm{~mm}$ thick, therefore it is recommended that sample tests should be $2 \mathrm{~mm}$ thick (mmeqAL = millimeters aluminum equivalent). Fenyo-Pereira ${ }^{10}$ for example, used 2-mm thick specimens to evaluate the optical density of porcelain. The specification 57 of the American Dental Association suggests the use of a 2-mm thick specimen to evaluate the optical density. After that, using diamond stones and sandpaper discs, the finishing and polishing work was done on the specimens. As porcelain had the manufacturer's properties, a digital pachymeter (Mitutoyo - São Paulo, Brasil) was used to certify that dimensions of the specimens were correct, and readings were analyzed on the display.

After preparation of the specimens they were put in a test tube, dipped into distilled water and kept in an oven at $37 \pm 1^{\circ} \mathrm{C}$ in order to simulate the oral environment ${ }^{16,17}$.

The samples were $\mathrm{X}$-rayed with the periapical machine Dentsply-Gendex 765DC® (Milan, Italy) set at $65 \mathrm{kVp}$ and $70 \mathrm{~mA}, 40 \mathrm{~cm}$ focal distance. The $40 \mathrm{~cm}$ focal distance is similar to the parallelism technique and exposure time of $0.02 \mathrm{~s}$. According to Medici-Filho, et al. ${ }^{17}$ and Takeshita, et al. ${ }^{22}$ it is ideal to get adequate contrast and density. To capture the images we used three digital x-ray systems, being two charge-coupled device (CCD), RVG (Trophy) and Visualix (Gendex), and one phosphor storage system - Digora (Soredex) for digital imaging.

The radiographic images are measured by means of a program named Image Tool for Windows version 1.28 (San Antonio, US) as for their digital optical density (gray tones). The gray tones measured by the program go from 0 to 255, then 256 different tones are recognized by the program ${ }^{17}$.

Twenty specimens were made i.e., 5 for each porcelain brand. Considering that 5 different areas were measured for each specimen, 100 measurements in porcelain were obtained. Five different areas in each sample were analyzed in order to minimize the error, so the mean of the 5 areas was used in this study (Fenyo-Pereira ${ }^{10}$ and Graziottin, et al. ${ }^{13}$ )

\section{RESULTS}

The mean optical density values were subjected to ANOVA (2-way) and Tukey tests $(\mathrm{p}<0.05)$. The porcelain presenting the highest optical density was Omega 900 and the lowest was Vitadur Alpha on the three digital systems 
(Figures 1, 2 and 3).

Table 1 represents the mean values of optical density for the different porcelain brands measured in gray tones.

Groups with the same letter have no statistically significant differences to each other.

\section{DISCUSSION}

Porcelain appeared in China at nearly 1000 years BC but it was first used to for fabrication of inlay/onlay as an esthetic means for caries restoration only 200 years ago; however, due to the high percentage of failures, those prostheses were substituted by gold during decades (Chain, et al. ${ }^{7}$ ). The inlays/onlays produced in gold had the disadvantage of not being esthetically favorable, so in the 60 s the porcelain was brought back to the market.

Today, the porcelain is the first material to be used for esthetic and functional restorations: it is chemically inert, has low thermal and electrical conductibility, is resistant to compression and has an excellent potential to simulate the appearance of natural teeth ${ }^{7,11}$.

The porcelain used in this research is classified as: feldspathic i.e., it has a great quantity of feldspar in its composition besides quartz and kaolin. It can be used for fabrication of inlay/onlay, ceramometal and porcelain veneers restorations. It can also be applied as a coating, since it presents excellent translucence characteristics and similar color as natural teeth. The Empress is reinforced with leucite, which provides good mechanical and visual properties and enables the porcelain to be used for jacket crowns, inlays and onlays ${ }^{20,24}$.

The composite resins used for class I and II restorations are accepted to be radiopaque ${ }^{2}$.

The radiopacity is a prerequisite for dental materials. In 1979 the Standard Association of Australia required the restorative materials of composite resin to have a high radiopacity. The American Dental Association ${ }^{2}$ included the radiopacity in the specifications for dental materials in 1981. Thus, it was established that dental materials should have same or greater radiopacity compared to radiolucent areas that suggest caries $1,12,13,15$.

In order to evaluate the radiopacity, authors like AbouTabl, et al. ${ }^{1}$ and Taira, et al..$^{21}$, suggested teeth cutting similar to the specimen for comparison, while $\mathrm{Cook}^{8}$ stated that aluminium is the material of choice because it presents the same linear coefficient of absorption as enamel.

The porcelain Omega 900 presented $1.6056 \mathrm{mmeqAl}$ (Digora), 1.8412 (RVG) and 1.8988 (Visualix). Empress presented 1.1815mmeqAl (Digora), 1.2788mmeqAl (RVG) and $1.3458 \mathrm{mmeqAl}$ (Visualix). The values of Simbios were 0.7643mmeqAl (Digora), 0.8724mmeqAl (RVG) and $1.0605 \mathrm{mmeqAl}$ (Visualix) and the Vitadur Alpha porcelain presented 0.8771mmeqAl (Digora), 0.8724 mmeqAl (RVG) and $0.8647 \mathrm{mmeqAl}$ (Visualix). Vitadur Alpha was the one that showed the lowest value, thus converging with FenyoPereira's ${ }^{10}$ studies. The Empress and Simbios had intermediate values and the Omega 900 presented the highest optical density.

Although the Omega 900 has shown statistically higher radiopacity values than enamel, Curtis, et al. ${ }^{9}$, consider that extremely high radiopacity values as that of metallic restorations e.g. silver amalgam can cover suspect areas and interfere with caries evaluation, as well as in cervical

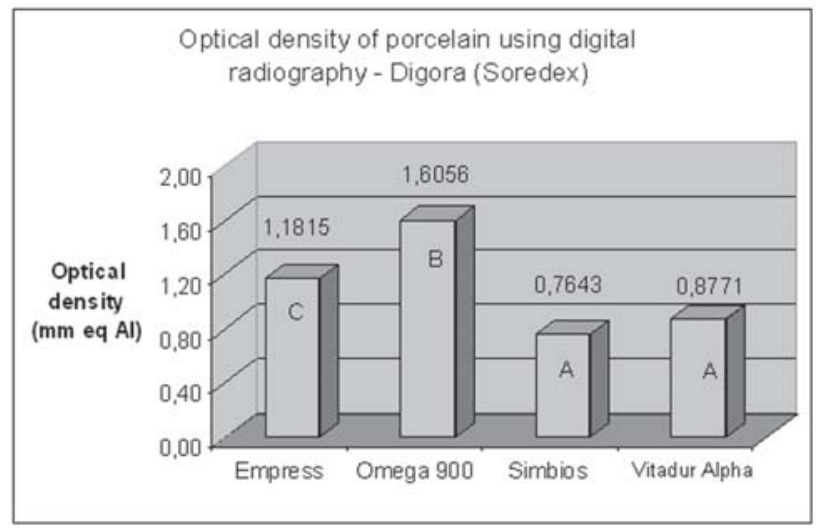

FIGURE 1- Mean values of optical density of porcelains. Means followed by same letters are not statistically different to each other at a significance level of 5\%. Digora (Soredex)

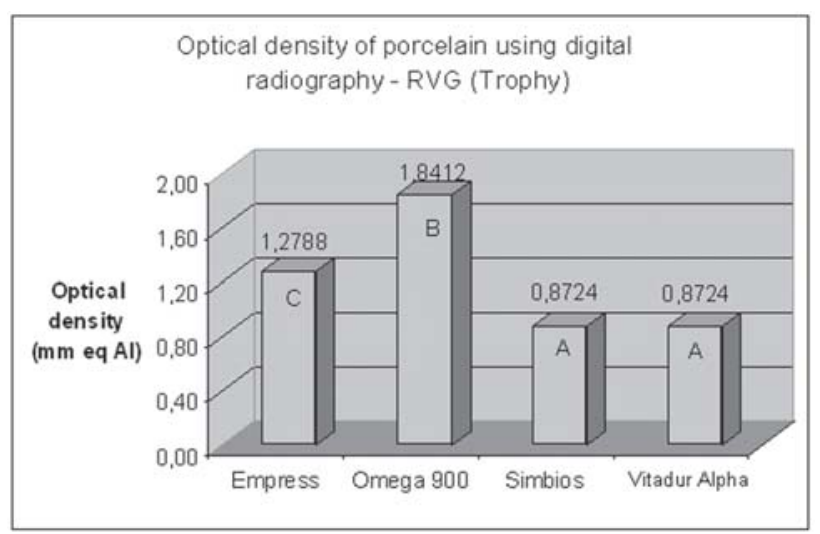

FIGURE 2- Mean values of optical density of porcelains. Means followed by same letters are not statistically different to each other at a significance level of 5\%. RVG (Trophy)

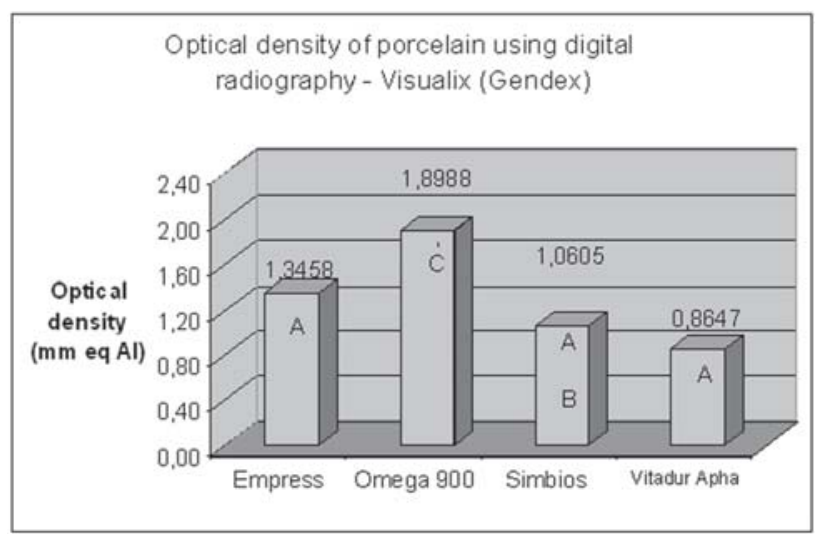

FIGURE 3- Mean values of optical density of porcelains. Means followed by same letters are not statistically different to each other at a significance level of $5 \%$.. Visualix (Gendex) 
TABLE 1- Mean optical density values in millimeters equivalent aluminum (mmeqAl) of the porcelains evaluated by the three different radiographic systems

\begin{tabular}{lllll}
\hline & $\begin{array}{l}\text { Empress } \\
\text { (mmeqal) }\end{array}$ & $\begin{array}{l}\text { Omega } 900 \\
\text { (mmeqal) }\end{array}$ & $\begin{array}{l}\text { Simbios } \\
\text { (mmeqal) }\end{array}$ & $\begin{array}{l}\text { Vitadur Alpha } \\
(\mathrm{mmeqal})\end{array}$ \\
Digora (Soredex) & $1.1815 \mathrm{a}$ & $1.6056 \mathrm{a}$ & $0.7643 \mathrm{~b}$ & $0.8771 \mathrm{~b}$ \\
RVG (Trophy) & $1.2788 \mathrm{a}$ & $1.8412 \mathrm{a}$ & $0.8724 \mathrm{~b}$ & $0.8724 \mathrm{~b}$ \\
Visualix (Gendex) & $1.3458 \mathrm{a}$ & $1.8988 \mathrm{a}$ & $1.0605 \mathrm{~b}$ & $0.8647 \mathrm{~b}$ \\
\hline
\end{tabular}

adaptation of class II restorations. This fact is due to an optical illusion described by Berry ${ }^{3}$ as mach bands, which are radiolucent areas along the cementoenamel junction. In his article he still points out that they are influenced by the density of the object, the type of film or even the projections on the radiography.

The objective of the restorations is to re-establish the occlusion. Therefore, they must offer proper characteristics for normal functioning of the stomatognathic system ${ }^{11}$. Radiopacity is essential to evaluate the restoration quality, Graziottin, et al. ${ }^{13}$, Fenyo-Pereira ${ }^{10}$, Loguercio, et al. ${ }^{15}$, MediciFilho, et al. ${ }^{17}$, used the digital image to measure the optical density. Therefore, digital radiography represents an alternative to measure the optical density, besides contributing for dental diagnosis.

\section{CONCLUSION}

1) The material that presented the highest degree of optical density was Omega 900;

2) Empress and Simbios presented intermediate optical density values;

3) Vitadur Alpha presented the lowest optical density value;

4) The optical density of porcelains was not influenced by the digital radiography systems.

\section{ACKNOWLEDGMENTS}

The authors thank all the Radiology Professors in the Department of Surgery, Periodontology and Radiology, of São Paulo State University. Säo José dos Campos, Dental School, Brazil.

\section{REFERENCES}

1- Abou-Tabl ZM, Tidy DC, Combe EC. Radiopacity of composite restorative materials. Br Dent J. 1979;147:187-8.

2- American Dental Association. Council on dental materiais, instruments and equipament. The desirability of using radiopaque plastics in dentistry. J Am Dent Assoc. 1981;102:347-1.
3- Berry HM. Cervical burnout and mach band: two shadows of doubt in radiologic interpretation of carious lesions. J Am Dent Assoc. 1983;106:622-5.

4- Borg E, Gröndahl HG. On the dynamic range of different X-ray photon detectors in intra-oral radiography. A comparison of image quality in film, charge-coupled device and storage phosphor systems. Dentomaxillofac Radiol. 1996;25:82-8.

5- Bouschlicher MR, Cobb DS, Boyer CB. Radiopacity of compomers, flowable and conventional resin composites for posterior restorations. Oper Dent. 1999;24:20-5.

6- Buonocore, M.G. A simple method of increasing the adhesion of acrylic filling materials to enamel surfaces. J Dent Res. 1955;34:84954.

7- Chain MC, Arcari GM, Lopes GC. Restaurações cerâmicas estéticas e próteses livres de metal. RGO. 2000;48:67-70.

8- Cook WD. An investigation of the radiopacity of composite restorative materials. Aust Dent J. 1981;26:105-12.

9- Curtis PM, Fraunhofer A, Farman AG. The radiographic density of composite resins. Oral Surg Oral Med Oral Pathol. 1990;70:226-30.

10- Fenyo-Pereira M. Avaliação, por meios dos métodos convencional e digital, da radiopacidade de diferentes marcas de porcelana utilizadas na confecção de inlay/onlay. São Paulo; 1998. [Tese de Livre-docência - Faculdade de Odontologia da USP].

11- Gonçalves JA, Melo EVS, Melo Júnior EJM, Raposo MJ. Critérios para seleção do material restaurador em função da oclusão em dentística restauradora. JBC. 1998;2:16-9.

12- Goshima T, Goshima Y. Optimum radiopacity of composite inlay materials and cements. Oral Surg Oral Med Oral Pathol. 1991;72:257-60.

13- Graziottin LRF, Costa NP, Silveira ID, Veeck EB. Resinas compostas compactáveis: comparação da densidade óptica utilizando radiografias digitais. Rev Fac Odont Univ Passo Fundo. 2001;6:3341

14- Khademi JA. Digital images \& sound. J Dent Educ. 1996;60:416.

15- Lutz F, Phillips RW, Roulet JF, Setcos JC. In vivo and vitro wear of potential posterior composites. J Dent Res. 1984;63:914-20.

16- Martins F, Delbem ACB, Santos LRA, Soares HLO, Martins EOB. Microhardness of resins as a function of color and halogen light. Pesqui Odontol Brás. 2002;16:246-50. 
17- Medici-Filho E, Castilho JCM, Takeshita WM, Santos LRA, Leite FPP, Valandro LF. An Investigation of optical density of prefabricated root canal posts using digital radiography. RBO. 2003;60:318-20.

18- Nelvig P, Wing K, Welander U. Sen-A-Ray. A new system for direct digital intraoral radiography. Oral Surg Oral Med Oral Pathol. 1992;74:818-23.

19- Oliveira AEF, Pistóia GD, Chicarelli M, Beltrami M. Aspectos de relevante importância na seleção de um sistema radiográfico digital. Rev Fac Odontol Univ Passo Fundo. 2000;5:21-5.

20- Palmeijer C H, Nilner K. Long term clinical evaluation of three luting materials. Swed Dent J. 1994;18:50-67.

21- Taira M, Toyooka H, Miyawaki H, Yamaki M. Studies on radiopaque composites containing $\mathrm{Zr02-Si02} \mathrm{fillers} \mathrm{prepared} \mathrm{by} \mathrm{the}$ sol-gel process. Dent Mater. 1993;9:167-71.

22- Takeshita WM, Santos LRA, Castilho JCM, Medici Filho E, Moraes LC, Sannomiya EK. An investigation of the optical density of composite resin using digital radiograph. Cienc Odontol Bras. 2004;7(2):6-11.

23- Tamburús JR. Radiopacity of the composite resins. Rev Odontol Univ São Paulo. 1990;4:103-7.

24- Van Dijken JWV, Wing KR, Ruyter IE. An evaluation of the radiopacity of composite restorative materials used in class I and class II cavities. Acta Odontol Scand. 1989;47:4001-17.

25- Wiliams JA, Billington RW. The radiopacity of glass ionomer of natural tooth substance and restouratives materials. J Oral Rehabil. 1990; $17: 245-8$ 